\title{
Diatomaceous earth effects on weevils with different susceptibility standard to phosphine
}

\author{
Patrícia M. da Conceição ${ }^{1}$, Lêda R. A. Faroni ${ }^{2}$, Adalberto H. Sousa ${ }^{3}$, \\ Marco A. G. Pimentel ${ }^{4} \&$ Romenique S. Freitas ${ }^{2}$
}

\begin{abstract}
A B ST RAC T
The aim of this study was to evaluate the insecticide activity of diatomaceous earth (DE), at different temperatures, on two populations of Tribolium castaneum and Rhyzopertha dominica previously diagnosed as resistant and susceptible to phosphine. The efficiency of DE in the control of the insects was evaluated at temperatures of $20,25,30,35$ and $40 \pm 2 \stackrel{\circ}{ }$. The experiments were accomplished in Petri dishes containing $35 \mathrm{~g}$ of whole-wheat grain treated with DE in the dose of $1.0 \mathrm{~kg} \mathrm{t}^{-1}$. The control was constituted by untreated wheat grain. Each Petri dish was infested with 30 adult insects. Insect mortality was registered seven days after the beginning of the bioassays. The experiment was conducted in a completely randomized design with three replications. The populations of $\mathrm{T}$. castaneum and $\mathrm{R}$. dominica, respectively, resistant and susceptible to phosphine have similar susceptibility patterns. The mortality of two populations of T. castaneum increased with increasing temperature. For R. dominica, the mortality did not change with the temperature.
\end{abstract}

Key words: Tribolium castaneum, Rhyzopertha dominica, alternative control

\section{Efeito da terra de diatomácea sobre carunchos com diferentes padrões de susceptibilidade à fosfina}

RESU M O

O objetivo deste trabalho foi avaliar a atividade inseticida da terra de diatomácea (TD), em diferentes temperaturas, em relação a duas populações de Tribolium castaneum e Rhyzopertha dominica previamente diagnosticadas como resistentes e susceptíveis à fosfina. A eficiência da TD foi avaliada nas temperaturas de $20,25,30,35$ e $40 \pm 2 \stackrel{\circ}{\circ}$ e os experimentos foram realizados em placas de Petri contendo $35 \mathrm{~g}$ de grãos inteiros de trigo, tratados com TD na dose de $1,0 \mathrm{~kg} \mathrm{t}^{1}$. 0 controle foi constituído de grãos de trigo não tratados; ressalta-se que cada placa de Petri foi infestada com 30 insetos adultos, cuja mortalidade foi contabilizada sete dias após o início dos bioensaios. 0 delineamento experimental utilizado foi o inteiramente casualizado, com três repetições. As populações de T. castaneum e R. dominica, respectivamente, resistentes e susceptíveis à fosfina apresentaram padrões de susceptibilidade semel hantes; por outro lado, a mortalidade das duas populações de T. castaneum aumentou com a elevação da temperatura embora para R. dominica a mortalidade não tenha variado com a temperatura.

Palavras-chave: Tribolium castaneum, Rhyzopertha dominica, controle alternativo 


\section{INTRODUCTION}

Brazil stands on the world stage as one of the largest producers of wheat grain, with a production capacity of 5.8 million $t$ in 2010/2011 crop season (CONAB, 2011). However, considerable grain losses are recorded because the insect pests attack. The species Rhyzopertha dominica (F.) (Coleoptera: Bostrichidae) and Tribolium castaneum (Herbst) (Coleoptera: Tenebrionidae) are important pests of wheat grain and its byproducts. They are found in virtually all storage and processing units of Brazil (Pereira, et al., 2008; Aguiar et al., 2010). The control of these insects is done with the use of protective insecticides, organophosphates and pyrethroids and the fumigant aluminum phosphide (Pimentel et al., 2009; Silveira et al., 2009; Sousa et al., 2009).

The continuous and indiscriminate use of phosphine from the 80's has caused the rapid evolution of resistance in populations of insect pests of stored products (Bell, 2000; Chaudhry, 2000; Collins et al., 2005). Recent studies report high levels of resistance to phosphine in Brazilian populations of $T$. castaneum, R. dominica and Oryzaephilus surinamensis (L.) (Coleoptera: Silvanidae) (Lorini et al., 2007; Pimentel et al., 2009), unlike previous studies in which the phosphine resistance in insect pests of stored products was a rare event and resistance levels were low (Champ \& Dyte, 1976; Pacheco et al., 1990).

The integration of non-chemical control methods can mitigate problems related to residues in food and pest resistance by overuse of these products (Beckel et al., 2004). The manipulation of grain temperature and the use of inert dusts such as diatomaceous earth are examples of promising nonchemical methods for the integrated management of insect pests of stored products (Flinn, 1998; Flinn \& Hagstrum, 2002). Diatomaceous earth is derived from sediment diatomaceous alga shell, and when in contact with the insects causes the removal of the wax layer of the cuticle, causing its death by desiccation (Korunic, 1998).

Diatomaceous earth mixed with grain via dusting or spraying, controls most of the pests effectively. This product works on larvae and adult insects, clinging to their bodies as they move on the surface or within the treated grain mass (Alves et al., 2006). Moreover, it presents some advantages such as low toxicity to mammals and environment; it does not leave harmful residues in the treated product; it is effective against insect species resistant to insecticides, and it is persistent and stable at high and low temperatures (Collins, 2006) .

The source of diatomaceous earth, the insect species, the water content and temperature of grain mass, the application method and exposure time are factors influencing the mortality of insect pests. In this respect, it was found that increasing the temperature can increase the movement of insects, providing the increase of the contact of this insects with the diatomaceous earth and consequently greater damage to the cuticle (Fields $\&$ Korunic, 2000). However, studies are needed on the toxicity of diatomaceous earth in combination with ambient temperature for populations of insect pests of stored products with different standard of susceptibility to the insecticides currently in use. These studies are important because populations of the same species with different genotypes may show different responses to the same treatment (McKenzie, 1996; Li et al., 2007).

Thus, the objective of this work was to evaluate the insecticide activity of the diatomaceous earth at different temperatures for populations of Tribolium castaneum and Rhyzopertha dominica, respectively, resistant and susceptible to phosphine.

\section{MATERIAL AND METHODS}

The bioassays were performed in the Laboratory of Integrated Pest Management, Universidade Federal de Viçosa. The influence of different temperatures $(20,25,30,35$ and 40 ${ }^{\circ} \mathrm{C}$ ) was investigated on the efficiency of diatomaceous earth in the control of the beetles $T$. castaneum and $R$. dominica.

\section{Insect populations}

Two populations of $T$. castaneum and two populations of $R$. dominica collected in the states of Mato Grosso, Minas Gerais and São Paulo were used (Table 1), which were previously diagnosed as resistant or susceptible to phosphine (Pimentel et al., 2007). The insects were created in glass jars with capacity for $1.5 \mathrm{~L}$, kept in climate B.O.D. chambers, under constant conditions of temperature $\left(30 \pm 2{ }^{\circ} \mathrm{C}\right)$, humidity $(70 \pm 5 \%)$ and scotophase of $24 \mathrm{~h}$. As food substrate, semi-milled wheat grain for T. castaneum and whole-wheat grain for $R$. dominica was used. The grain presented a water content of $13 \%$ wet basis (wb) and had been fumigated with phosphine $\left(\mathrm{PH}_{3}\right)$ and kept under refrigeration $\left(-18^{\circ} \mathrm{C}\right)$ to prevent reinfestation.

Table 1. O rigin, place and time of populations collection of Tribolium castaneum and Rhyzopertha dominica

\begin{tabular}{clll}
\hline \multicolumn{1}{c}{ Species } & \multicolumn{1}{c}{ City } & \multicolumn{1}{c}{ Collection site } & Year \\
\multirow{2}{*}{ T. castaneum } & Água Boa, MT & Conventional Warehouse & 2004 \\
& Bom Despacho, MG & Metal silo & 2005 \\
\hline \multirow{2}{*}{ R. dominica } & Piracicaba, SP & Laboratory & 2004 \\
& Uberlândia, MG & Metal silo & 2004 \\
\hline
\end{tabular}

$\mathrm{R}=$ resistant to phosphine, $\mathrm{S}=$ Susceptible to phosphine (Pimentel et al., 2007)

\section{Toxicity bioassays of diatomaceous earth}

Diatomaceous earth used was the national brand KeepDry with at least $86 \%$ of amorphous silicon dioxide $\left(\mathrm{SiO}_{2}\right)$ particles of about $15 \mu \mathrm{m}$ and apparent density of $200 \mathrm{~g} \mathrm{~L}^{-1}$; light beige color, insoluble in water and aspect of dry powder.

To evaluate the insecticidal activity of diatomaceous earth on $T$. castaneum and $R$. dominica, experiments were performed in Petri dishes $(140 \times 10 \mathrm{~mm})$ containing $35 \mathrm{~g}$ of whole wheat grain with water content of $13 \% \mathrm{wb}$, treated with diatomaceous earth at a dose of $1.0 \mathrm{~kg} \mathrm{t}^{-1}$ of grain. Each Petri dish was infested with 30 adult insects of $T$. castaneum or $R$. dominica, unsexed, with age varying from one to three weeks. Then, they were kept in a BOD chambers at temperatures of 20, 25, 30, 35 and 40 $\pm 2{ }^{\circ} \mathrm{C}$, under constant conditions of relative humidity (70 \pm $5 \%$ ) and scotophase of 24 hours. The control treatment was conducted under the same conditions, using, however, wholewheat grain untreated with diatomaceous earth. The insect mortality was recorded seven days after the start of bioassays 
and was considered as dead insect the one which did not move on touching.

\section{Statistical analyses}

The experimental design used was a completely randomized design with three replications. Mortality data from each population were adjusted by the Abbott's formula (Abbott, 1925) and submitted to analysis of covariance, using SAS software (SAS Institute, 2002). For significant interactions, we performed the unfolding of the data. From the values obtained, we made linear regression analysis was done as a function of temperature, using the software Sigma Plot, version 7.0 (SPSS, 2001).

\section{RESULTS AND DISCUSSION}

Mortality did not vary significantly among the populations of $T$. castaneum $\left(\mathrm{F}_{1 \cdot 20}=0.96, \mathrm{P}=0.34\right)$, however, varied significantly among temperatures $\left(\mathrm{F}_{4: 20}=34.80, \mathrm{P}=0.00\right)$. Significant interaction was found for population $\times$ temperature $\left(\mathrm{F}_{4 ; 20}=5.89, \mathrm{P}=0.00\right)$. As no significant difference was found between the mortality of populations of $T$. castaneum resistant and susceptible to phosphine, mortality data from two populations of $T$. castaneum were submitted together to adjustments of regression as a function of temperature (Figure 1). It is observed that insect mortality increased with increasing temperature, with average increase of $79.64 \%$ between the temperatures of 20 and $40{ }^{\circ} \mathrm{C}$. The insect mortality rate was significantly high from $30^{\circ} \mathrm{C}$.

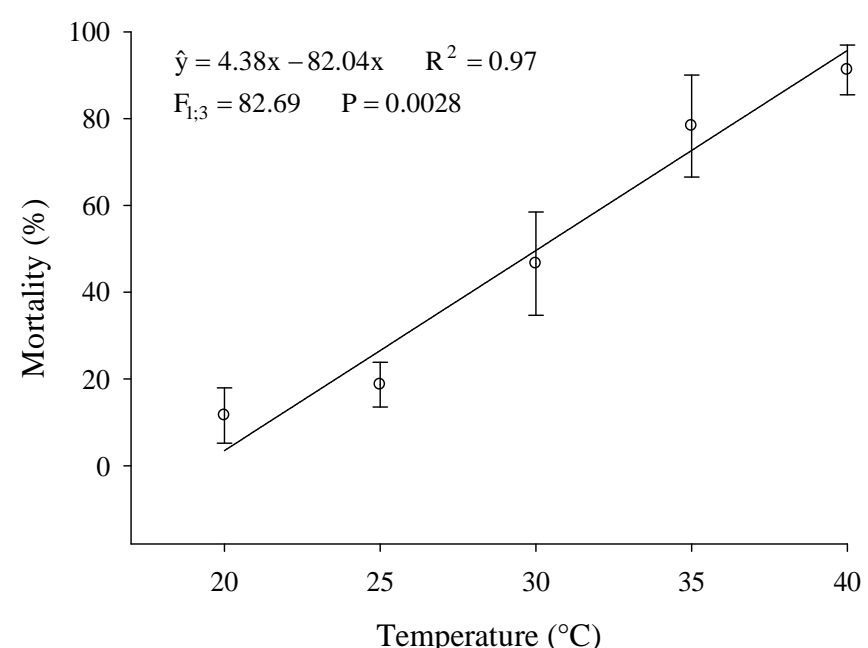

The symbols (o) represent the average mortality among the population, resistant and susceptible at each temperature

Figure 1. M ortality (\%) of Tribolium castaneum in wheat grain treated with diatomaceous earth at different temperatures

Regarding the mortality of $R$. dominica, no significant variation was observed among populations $\left(\mathrm{F}_{1: 20}=0.12, \mathrm{P}=\right.$ 0.73), temperatures $\left(\mathrm{F}_{4: 20}=1.02, \mathrm{P}=0.42\right)$ and interaction between these two variables $\left(\mathrm{F}_{4 ; 20}=3.01, \mathrm{P}=0.04\right)$. Because there were no significant effect on $R$. dominica, therefore data were not adjusted to regression models for insect mortality as a function of temperature. The mortality is represented by the average number of dead insects among the population, resistant and susceptible at each temperature (Figure 2).

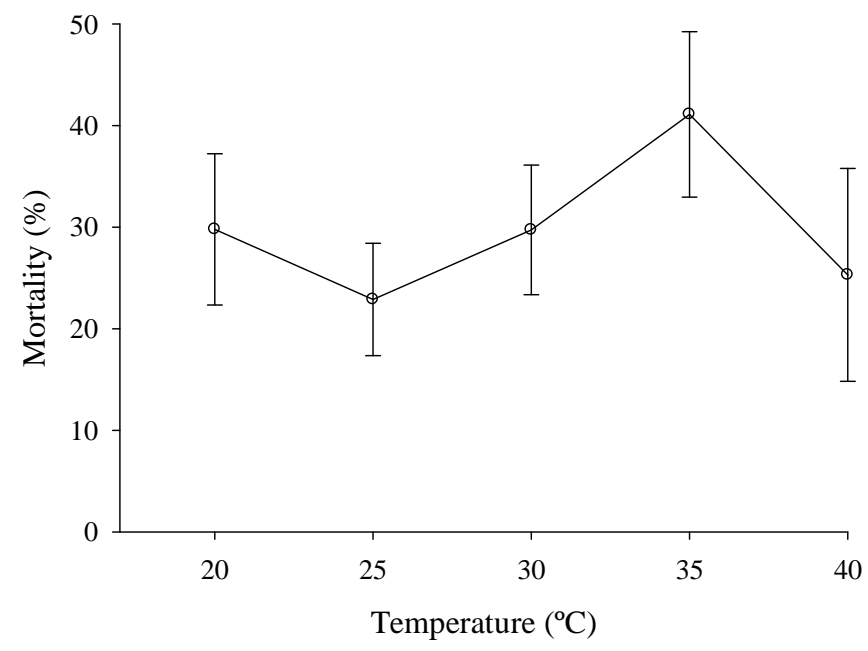

The symbols (0) represent the average of mortality among the population, resistant and susceptible at each temperature

Figure 2. Mortality (\%) of Rhyzopertha dominica in wheat grain treated with diatomaceous earth at different temperatures

The efficacy of diatomaceous earth on the mortality of insect pests of stored products is usually affected by several factors among which stands out the temperature (Chanbang et al., 2007). Generally, the increase in temperature favors the increase in the effectiveness of this product by stimulating the movement of insects within the grain mass, providing an increased contact of them, with the diatomaceous earth (Chanbang et al., 2007; Vayias et al., 2009). In addiction, the insects have higher respiration rates at higher temperatures (Cotton, 1932), and consequently the greater water loss via spiracles promoting desiccation (Zachariassen, 1991). However, it was shown in some studies that the insect mortality can vary between species (Arthur, 2000; Vayias \& Athanassiou, 2004; Athanassiou et al., 2005; Vayias et al., 2009).

In this study, an increase was observed in the efficiency of diatomaceous earth on the mortality of $T$. castaneum when using higher temperatures. However, there was no effect of temperature on the toxicity of diatomaceous earth on populations of $R$. dominica. The lower susceptibility of adults of $R$. dominica compared to $T$. castaneum can be attributed to lower mobility of the first species in grain mass, which reduces their contact with the diatomaceous earth. The lower mobility of adults of $R$. dominica occurs because they have short legs, and therefore, they walk slowly when compared to adults of other species such as T. cataneum (Faroni \& Souza, 2006).

The results obtained in this study suggest that the resistance to phosphine on $T$. castaneum and $R$. dominica populations did not influence the effect of diatomaceous earth on these two insect species. As the populations of T. castaneum and $R$. dominica showed uniformity of response among themselves, regardless to be resistant or susceptible to phosphine, it can be stated that the mechanism that these populations used to become resistant to phosphine has no 
effect on the influence of the diatomaceous earth and do not prevent its action in such cases. Thus, the diatomaceous earth is an alternative product to phosphine.

\section{Conclusions}

1. Diatomaceous earth is a potential alternative to be used in the development of strategies for management of phosphine resistance in insect pests of stored products, since a uniform response was observed among populations of $T$. castaneum and $R$. dominica both resistant and susceptible to phosphine.

2. Considering that diatomaceous earth was efficient at temperatures ranging from 20 to $40{ }^{\circ} \mathrm{C}$ for both $T$. castaneum and $R$. dominica, it is concluded that treatment of grains with this product may be indicated for management of phosphineresistant insect pests of stored products in tropical regions.

\section{LITERATURE CITED}

Abbott, W. S. A method of computing the effectiveness of an insecticide. Journal of Economic Entomology, v.18, p.265267, 1925.

Aguiar, R. W. S.; Faroni, L. R. D.; Guedes, R. N. C. ; Sousa, A. H.; Rozado, A. F. Toxicidade da combinação de dióxido de carbono e fosfina sob diferentes temperaturas para Tribolium castaneum. Revista Brasileira de Engenharia Agrícola e Ambiental, v.14, p.881-886, 2010.

Alves, L. F. A.; Buzarello, G. D.; Oliveira, D. G. P.; Alves, S. B. Ação da terra de diatomácea contra adultos do cascudinho Alphitobius diaperinus (Panzer, 1797) (Coleoptera: Tenebrionidae). Arquivos do Instituto Biológico, v.73, p.115118, 2006.

Arthur, F. H. Toxicity of diatomaceous earth to red flour beetles and confused flour beetles (Coleoptera: Tenebrionidae): effects of temperature and relative humidity. Journal of Economic Entomology, v.93, p.526-532, 2000.

Athanassiou, C. G.; Vayias, B. J.; Dimizas, C. B.; Kavallieratos, N. G.; Papagregoriou, A. S.; Buchelos, C. T. Insecticidal efficacy of diatomaceous earth against Sitophilus oryzae (L.) (Coleoptera: Curculionidae) and Tribolium confusum du Val (Coleoptera: Tenebrionidae) on stored wheat: influence of dose rate, temperature and exposure interval. Journal of Stored Products Research, v.41, p.47-55, 2005.

Beckel, H.; Lorini, I.; Lázzari, S. M. N. Comportamento de adultos de diferentes raças de Rhyzopertha dominica (Fabricius) (Coleoptera, Bostrichidae) em superfície tratada com deltamethrin. Revista Brasileira de Entomologia, v.48, p.115118, 2004.

Bell, C. H. Fumigation in the 21 st century. Crop Protection, v.19, p.563-569, 2000.

Champ, B. R.; Dyte, C. E. Informe de la prospección mundial de la FAO sobre susceptibilidad a los insecticidas de las plagas de granos almacenados, Roma: FAO, 1976. 356p.
Chanbang,Y;; Arthur, F. H.; Wilde, G. E.; Throne, J. E. Efficacy of diatomaceous earth to control Rhyzopertha dominica (F.) (Coleoptera: Bostrichidae) in rough rice: Impacts of temperature and relative humidity. Crop Protection, v.26, p.923-929, 2007.

Chaudhry, M. Q. Phosphine resistance: a growing threat to an ideal fumigant. Pesticide Outlook, v.11, p.88-91, 2000.

Collins, D. A. A review of alternatives to organophosphorus compounds for the control of storage mites. Journal of Stored Products Research, v.42, p.395-426, 2006.

Collins, P. J.; Daglish, G. J.; Pavic, H.; Kopittke, R. A. Response of mixed-age cultures of phophine-resistance and susceptible strains of lesser grain borer, Rhyzopertha dominica, to phosphine at a range of concentrations and exposure periods. Journal of Stored Products Research, v.41, p.373-385, 2005.

CONAB - Companhia Nacional de Abastecimento. Acompanhamento da safra brasileira de grãos, safra 2010/ 2011 - 5 ${ }^{\circ}$ levantamento, fevereiro de 2011. http:// www.conab.gov.br. 19 Fev. 2011.

Cotton, R. T. The relation of respiratory metabolism of insects to their susceptibility to fumigants. Journal of Economic Entomology, v.25, p.1088-1103, 1932.

Faroni, L. R. D’A.; Sousa, A. H. Aspectos biológicos e taxonômicos dos principais insetos-praga de produtos armazenados. In: Almeida, F. A. C.; Duarte, M. E. M.; Cavalcanti-Mata, M. E. R. M. (ed.) Tecnologia de armazenagem em sementes. Campina Grande: UFCG, 2006. Cap.7, p.371-402.

Fields, P.; Korunic, Z. The effect of grain moisture content and temperature on the efficacy of diatomaceous earths from different geographical locations against stored-product beetles. Journal of Economic Entomology, v.13, p.1-13, 2000.

Flinn, P. W. Temperature effects on efficacy of Choetospila elegans (Hymenoptera: Pteromalidae) to suppress Rhyzopertha dominica (Coleoptera: Bostrichidae) in stored wheat. Journal of Economic Entomology, v.91, p.320-323, 1998.

Flinn, P. W.; Hagstrum, D. W. Temperature-mediated functional response of Theocolax elegans (Hymenoptera: Pteromalidae) parasitizing Rhyzopertha dominica (Coleoptera: Bostrichidae) in stored wheat. Journal Stored Products Research, v.38, p.185-190, 2002.

Korunic, Z. Review diatomaceous earths, a group of natural insecticides. Journal of Stored Products Research, v.34, p.8797, 1998.

Li, Z. M.; Liu, S. S.; Liu, Y. Q.; Ye, G. Y. Temperature-related fitness costs of resistance to spinosad in the diamondback moth, Plutella xylostella (Lepidoptera: Plutelidae). Bulletin of Entomological Research, v.97, p.627-635, 2007.

Lorini, I.; Collins, P. J.; Daglish, G. J.; Nayak, M. K.; Pavic, H. Detection and characterisation of strong resistance to phosphine in Brazilian Rhyzopertha dominica (F.) (Coleoptera: Bostrychidae). Pest Management Science, v.63, p.358-364, 2007.

Mckenzie, J.A. Selection Against Resistant Phenotypes. In: McKenzie, J. A. Ecological and evolutionary aspects of insecticide resistance, Austin: Academic Press, 1996. 185p. 
Pacheco, I. A.; Sartori, M. R.; Taylor, R. W. D. Levantamento de resistência de insetos-praga de grãos armazenados à fosfina, no estado de São Paulo. Coletânia do ITAL, v.20, p.144-154, 1990.

Pereira, A. M. ; Faroni, L. R. D’A.; Sousa, A. H. ; Urruchi, W. I.; Paes, J. L. Influência da temperatura da massa de grãos sobre a toxicidade do ozônio a Tribolium castaneum. Revista Brasileira de Engenharia Agrícola e Ambiental, v. 12, p. 493-497, 2008.

Pimentel, M. A. G.; Faroni, L. R. D’ A.; Guedes, R. N. C.; Sousa, A. H.; Tótola, M. R. Phosphine resistance in Brazilian populations of Sitophilus zeamais Motschulsky (Coleoptera: Curculionidae). Journal of Stored Products Research, v.45, p.71-74, 2009.

Pimentel, M. A. G.; Faroni, L. R. D.; Tótola, M. R.; Guedes, R. N. C. Phosphine resistance, respiration rate and fitness consequences in stored-product insects. Pest Management Science, v.63, p.876-881, 2007.

SAS Institute. SASD STAT User's guide, Version 8.0. Cary: SAS Institute Inc., 2002.

Silveira, R. D.; Faroni, L. R. D.; Guedes, R. N. C.; Queiroz, M. E. L. R.; Pimentel, M. A. G. Biological activity and persistence of pirimiphos-methyl applied to maize grain at different temperatures. Revista Brasileira de Engenharia Agrícola e Ambiental, v.13, p.729-733, 2009.
Sousa, A. H.; Faroni, L. R. D.; Pimentel, M. A. G.; Guedes, R. N. C. Developmental and population growth rates of phosphine-resistant and -susceptible populations of storedproduct insect pests. Journal of Stored Products Research, v.45, p.241-246, 2009.

SPSS. Sigma Plot user's guide, Version 7.0. Chicago: SPSS, 2001.

Vayias, B. J.; Athanassiou, C. G. Factors affecting efficacy of the diatomaceous earth formulation SilicoSec against adults and larvae of the confused beetle Tribolium confusum du Val (Coleoptera: Tenebrionidae). Crop Protection, v.23, p.565-573, 2004.

Vayias, B. J.; Athanassiou, C. G.; Buchelos, C. T. Effectiveness of spinosad combined with diatomaceous earth against different European strains of Tribolium confusum du Val (Coleoptera: Tenebrionidae): Influence of commodity and temperature. Journal of Stored Products Research, v.45, p.165-176, 2009.

Zachariassen, K. E. Routes of transpiratory water loss in a dryhabitat tenebrionid beetle. Journal of Experimental Biology, v.157, p.425-437, 1991. 